\title{
Evaluation of the Effectiveness of School Attack 2019 Program at SMK Skudai, Johor
}

\author{
Rafidah Muhamad ${ }^{1}$, Amalina Yusup $^{2}$, Asraful Syifaa' Ahmad ${ }^{1, *}$, Nabilah Kassim³, \\ Fathiah Nabila Mohd Daud ${ }^{4}$, Liza Md Salleh ${ }^{5}$, D. Dahyuna Mohd Yunos ${ }^{5}$, \\ Nursyazwani Aznan ${ }^{6}$, Rafidah Abd Rahim ${ }^{6}$, Mohd Iskandar Ishak ${ }^{7}$, Sarah Alia \\ Norazlan $^{2}$, Filzah Hazirah Jaffar ${ }^{5}$, Nurlaila Syamsul Bahri ${ }^{5}$, Nurul Diyana Zainal ${ }^{3}$, \\ Muhamad Farhin Harun ${ }^{1}$
}

\author{
${ }^{1}$ School School of Computing, Faculty of Engineering, Universiti Teknologi Malaysia \\ ${ }^{2}$ Faculty of Built Environment \& Surveying, Universiti Teknologi Malaysia \\ ${ }^{3}$ Department of Physics, Faculty of Science, Universiti Teknologi Malaysia \\ ${ }^{4}$ Azman Hashim International Business School, Universiti Teknologi Malaysia \\ ${ }^{5}$ School of Chemical and Energy Engineering, Universiti Teknologi Malaysia \\ ${ }^{6}$ Deputy Vice Chancellor's Office (Research and Innovation), Universiti Teknologi Malaysia \\ ${ }^{7}$ Deputy Vice Chancellor's Office (Student Affairs) Universiti Teknologi Malaysia \\ ${ }^{*}$ Corresponding author. Email: asrafulsyifaa.ahmad@gmail.com
}

\begin{abstract}
The Malaysian Education Development Plan 2013-2025 (PPPM 2013-2025) is a plan that emphasizes the importance of applying Science, Technology, Engineering and Mathematics (STEM) to meet Industry 4.0 challenges. This is to produce skilled human capital in the area of future technology that is at the core of Industry 4.0. In Malaysia, the implementation of STEM is seen in the second wave as governments, statutory bodies, associations, non-governmental organizations (NGOs) and external agencies work together to promote STEM to the community. In support of this initiative, a program called School Attack 2019 was held at SMK Skudai attended by 100 students selected from Form One. There are six different modules designed for the syllabus for this school and are taught in a fun way by students from various backgrounds from Universiti Teknologi Malaysia (UTM). Therefore, the purpose of this paper is to study and analyze the effectiveness of the module, facilitator efficiency and evaluate the success of the program. The outcomes show that understudy fulfilment continuously increments for the best-oversaw modules, demonstrating that proactive execution of proper reactions to understudy criticism on their learning venture is powerful in improving understudy fulfilment and learning.
\end{abstract}

Keywords: Science, Technology, Engineering, Mathematics, Education

\section{INTRODUCTION}

Malaysia puts high significance on training as a driver for accomplishing the objective of turning into a created country fit for satisfying the difficulties and needs of the economy driven by Science, Technology, Engineering and Mathematics (STEM) by 2020 [1]. All in all, the Malaysian government has presented a 60: 40 Science/Technical: Literature in training since 1967, and specifically started to execute the arrangement in 1970 . The strategy alludes to the Ministry's mean to build the proportion of understudies with critical STEM training contrasted with the individuals who center around Literature. By and by, the strategy is accounted for to be a disappointment [2].

It has been accounted for that in 2011, only $45 \%$ of students graduating moving on from the educational system were science students. The level of secondary students who are qualified for a science course after the PMR, yet quitting it has expanded by practically $15 \%$. This raises worries about the capacity of the training framework to give enough STEM graduates to meet the financial needs of the nation. As per the National Council for Scientific Research and Development, Malaysia will require 493,830 researchers and architects by 2020 . As per current movement and advancement, the Ministry of Science, Technology and Innovation (MOSTI) gauges there will be 236,000 labor deficiencies. In addition, the results of the PISA 2009+ (Malaysia's first entry) show that Malaysia still has to work towards delivering STEMbased education to students. PISA 2009+ is a direct comparative method of quality education across multiple systems. This method assesses various cognitive skills such as application and reasoning. The results show that Malaysia ranks third among 74 participating countries, and 
below the international average and the Organization for Economic Co-operation and Development (OECD). These figures indicate the need for interventions to achieve the goal of increasing STEM graduates and enhancing future student achievement.

Therefore, the government decided to revise the policy and proposing the Malaysian Education Development Plan 2013-2025 (PPPM 2013-2025). One of the action plans is to strengthen STEM delivery across the education system, which is divided into three waves. Wave 1 will focus on strengthening the existing program and encouraging upper and lower secondary students to pursue a science stream. Wave 2 emphasized the building of the foundation by increasing support from various stakeholders in the informal learning sector. Wave 3 will evaluate the initiative and provide an action plan for further innovation. Driven by this initiative, Kolej Datin Seri Endon (KDSE), Universiti Teknologi Malaysia (UTM) led by the Student College Committee took the leapt to develop a STEMbased teaching and learning program for high school students. This program is designed to teach in a more enriching and interesting manner, and interdisciplinary in nature to keep curiosity alive as encouraged by [3] through the concept of fun learning activities.

This article consists of five parts. Section 2 presents related works on STEM education methods. The modules created for STEM training is clarified in Section 3. Results and assessment are discussed in the Section 4. The conclusion and future studies are explained Section 5.

\section{LITERATURE REVIEW}

According to [4], in order to achieve the 21st-century skills for Malaysia context, the currently existing approach in Malaysian Education Curriculum needs to be changed into an interdisciplinary approach called STEM curriculum as it be defined as a can be characterized as an information view and educational program approach that intentionally applies methodology and language from more than one discipline to examine a central theme, issue, problem, topic, or experience [5].

Hardy et al., expressed that an interdisciplinary methodology is executed with the possibility that subjectexplicit learning is neither significant or applicable to youthful school leavers in the 21st-century [6]. Setting them up without offering the presentation and involvement in designing and innovation, will neglect to make due in the competitive environment [7], [8].

Jayarajah et al. expressed that however Malaysian exploration in the innovation and designing fields is entrenched and is in actuality actually succeeding, research patterns show that the accentuation in both these fields has been centred around college graduates [9]. This demonstrates research on innovation and designing has been centred around the most progressive degree of training, leaving understudies and instructors in essential and optional schools with significantly less consideration. DeJarnette focused on that less open doors exist for elementary students and their teachers [10]. Exploration has indicated that early presentation to STEM activities and exercises decidedly impacts rudimentary students' perceptions and dispositions [10]-[12]. DeJarnette included that by catching understudies' enthusiasm for STEM content at a previous age, a proactive methodology can guarantee that understudies are on target through essential and optional school to finish the required coursework for sufficient planning to enter STEM degree programs at establishments of higher learning. These interests could also lead students to pursue their careers based on STEM education [13].

\section{METHODOLOGY}

\subsection{Research Design and Sample}

This program employed a basic survey towards the effectiveness of the program, modules, and facilitators. The sample comprised of 100 Form One students. All the students from the sample completely answered the survey form. These students consist of 57 females and 43 males. Table 1 shows the distribution of these students in each gender while Table 2 shows the list of modules conducted.

Table 1 Number of students by gender

\begin{tabular}{|c|c|}
\hline Gender & Total \\
\hline Male & 43 \\
\hline Female & 57 \\
\hline Total & $\mathbf{1 0 0}$ \\
\hline
\end{tabular}

\subsection{Instrument}

The questionnaire is divided into two sections, namely Section A and Section B. Section A contained items on the students' demographic data such as sex. Section B contained 18 things on appraisals in STEM-related subjects as indicated by the pertinence towards every module being appeared to the understudies. These things are isolated into six (6) modules where every module has three questions. The STEM-related subjects in the optional school educational program are Biology, Chemistry, Physics, Science, Mathematics and Additional Mathematics. All the modules are innovatively planned by the prospectus by Malaysia Education Ministry. Meanwhile, all the items in the survey form had a fourpoint Likert scale response option, namely strongly disagree, disagree, agree and strongly agree. The students' responses to each item received weighted values from 1 (strongly disagree) to 4 (strongly agree). 
Table 2. Modules designed and their description

\begin{tabular}{|c|c|}
\hline Mod & Materials and Description \\
\hline $\begin{array}{l}\text { Water Under } \\
\text { Candle }\end{array}$ & $\begin{array}{l}\text { - To understand how temperature } \\
\text { affects pressure } \\
\text { - Cover a burning candle with a pitcher } \\
\text { so that the candle is in an air-tight } \\
\text { room sealed by the water at the } \\
\text { ground }\end{array}$ \\
\hline \begin{tabular}{|l|} 
Pressure \\
Fountain
\end{tabular} & $\begin{array}{l}\text { - To demonstrate an understanding of } \\
\text { how air pressure works } \\
\text { The air inside the inflatable is feeling } \\
\text { the squeeze as it is gotten by the } \\
\text { elastic. At the point when you place } \\
\text { the swelled inflatable on head of the } \\
\text { container, the gaseous tension on } \\
\text { head of the jug gets higher. That } \\
\text { pushes down on the water in the } \\
\text { container, pushing it through the } \\
\text { straw and making the wellspring } \\
\text { more grounded. }\end{array}$ \\
\hline Photosynthesis & $\begin{array}{l}\text { To study the presence of starch in } \\
\text { leaves as the presence of sunlight } \\
\text { helps plants in the process of } \\
\text { photosynthesis and starch production. } \\
\text { Use leaves, tissue paper, syrup and } \\
\text { methanol }\end{array}$ \\
\hline $\begin{array}{l}\text { Elephant's } \\
\text { Toothpaste }\end{array}$ & $\begin{array}{l}\text { - The froth you made in this exemplary } \\
\text { Elephant's Toothpaste response is } \\
\text { extra-extraordinary in light of the fact } \\
\text { that each minuscule froth bubble is } \\
\text { loaded up with oxygen } \\
\text { This module is called Elephant's } \\
\text { Toothpaste on the grounds that the } \\
\text { compound response delivers an } \\
\text { enormous frothy wreck that seems as } \\
\text { though toothpaste spurting out of a } \\
\text { cylinder. It is huge to the point that } \\
\text { solitary an elephant could utilize } \\
\text { toothpaste this enormous }\end{array}$ \\
\hline Oobleck & $\begin{array}{l}\text { Oobleck is a mixture that has fluid } \\
\text { and solid properties depending on the } \\
\text { force applied to the Oobleck mixture. } \\
\text { If the applied force is high, Oobleck } \\
\text { will show solid properties. } \\
\text { Meanwhile, if the applied force is } \\
\text { low, the liquid characteristics are } \\
\text { shown } \\
\text { Materials are corn flour, water and } \\
\text { food coloring. }\end{array}$ \\
\hline Dry Ice & $\begin{array}{l}\text { Dry ice is a carbon dioxide gas in } \\
\text { solid form } \\
\text { The module planned to put part of } \\
\text { the dry ice in hot water, causing it to } \\
\text { produce steam or mist clouds. }\end{array}$ \\
\hline
\end{tabular}

\section{RESULTS AND FINDINGS}

This section discusses the effectiveness of the program through the feedback survey forms. There are three important elements been asses through the feedback form which is; (A) The aim and objectives of the program, (B) how the program been managed and lastly (C) the effectiveness of the program from the student's perspectives. All of these criteria are important to ensure the effectiveness of the programs and for an improvement in the future. The details elements in the feedback forms are as stated in Table 3 meanwhile the survey results are tabulated in Figure 1.

Table 3. The detail elements asses for the program

\begin{tabular}{|c|c|}
\hline Code & Assessment \\
\hline \multicolumn{2}{|r|}{ A: Program } \\
\hline A1 & $\begin{array}{l}\text { The objective of this program is to provide } \\
\text { exposure to Science, Technology, Engineering } \\
\text { and Mathematics (STEM). }\end{array}$ \\
\hline A2 & $\begin{array}{l}\text { The content of the program is in line with } \\
\text { school learning. }\end{array}$ \\
\hline A3 & $\begin{array}{l}\text { The activity of each station is effectively } \\
\text { managed. }\end{array}$ \\
\hline A4 & $\begin{array}{l}\text { Use of effective teaching aids / experimental } \\
\text { materials. }\end{array}$ \\
\hline A5 & Deliverable and effective facilitator. \\
\hline \multicolumn{2}{|r|}{ B: Program Management } \\
\hline $\mathrm{B} 1$ & The program execution journey went smoothly \\
\hline $\mathrm{B} 2$ & $\begin{array}{l}\text { The time allocated for each station is } \\
\text { appropriate. }\end{array}$ \\
\hline \multicolumn{2}{|r|}{ C: Program Effectiveness } \\
\hline $\mathrm{C} 1$ & $\begin{array}{l}\text { My understanding of Science, Technology, } \\
\text { Engineering and Mathematics (STEM) has } \\
\text { improved since before joining the program. }\end{array}$ \\
\hline $\mathrm{C} 2$ & $\begin{array}{l}\text { After this program I can apply the knowledge } \\
\text { learned. }\end{array}$ \\
\hline $\mathrm{C} 3$ & $\begin{array}{l}\text { I can tell about the knowledge learned } \\
\text { throughout this program to my family and } \\
\text { friends }\end{array}$ \\
\hline $\mathrm{C} 4$ & $\begin{array}{l}\text { Overall the program was successful and } \\
\text { rewarding. }\end{array}$ \\
\hline
\end{tabular}

Based on the analysis, the majority of the students' answers either 'Agree' or 'Totally Agree' towards all the elements been asked which bring out the total of minimum $75 \%$ to $99 \%$ of students. Meanwhile the remainder engaged in A2 (8\%), A3 (1\%), A4 (5\%), A5 (7\%), B1 (3\%), B2 (15\%), C1 (8\%), C2 (8\%), C3 (6\%) and C4(1\%). The A2 element which asked either the content of the program is in line with school learning engaged in $8 \%$ that falls into the 'Disagree' and 'Totally Disagree' range. From here, we would revised again several modules to ensure that the modules are syllabus-based. However, majority students agree with the suitability of the modules presented. Meanwhile, for B2 element that asked either the time allocated for each station is appropriate shows 12 students disagree. During the event day, we allocated 15 minutes each stations before the students move to the next stations. This shows that we need to consider the number 


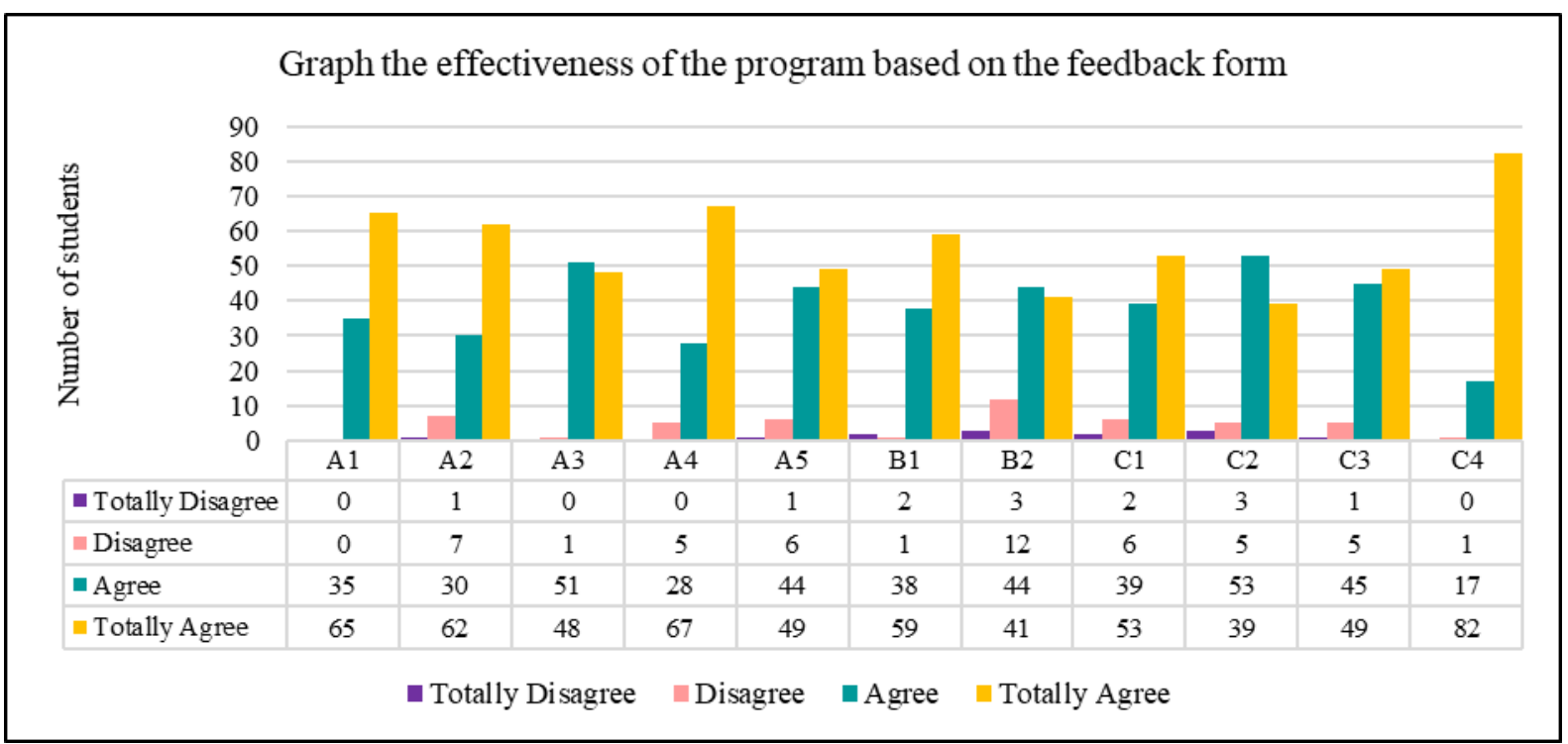

Figure 1 The result from feedback form

\section{CONCLUSION}

A study done by [9] stated that STEM education in Malaysia is more focused on higher education and less emphasis on the school level. This is not surprising because, in universities and colleges, many Malaysian students are offered engineering courses as well as other STEM related courses for example the Engineering Design approach is not widespread for all schools. Thus, as a conclusion, this study is expected to be a catalyst for STEM students. The collaboration between universities, schools and other teachers also provide opportunities for UTM students to develop communication skills, leadership skills and thinking skills.

\section{ACKNOWLEDGMENT}

The authors would like to express their appreciation for the support of Kolej Datin Seri Endon, Universiti Teknologi Malaysia, Tourism Malaysia, SMK Skudai, Skudai, and Jabatan Pendidikan Negeri Johor for the program facilities and financial support.

\section{REFERENCES}

[1] Kementerian Pendidikan Malaysia, "20132025, Malaysia Education Blueprint." Accessed: Jun. 28, 2020. [Online].

[2] Y. Mohamad, "Basic education curriculum revisited: A look at the current content and reform in
Malaysia," in SEAMEORETRAC 11th Governing Board Meeting and Conference, Institute Aminuddin Baki Malaysia, 2008.

[3] M. B. Yarker and S. Park, "Analysis of teaching resources for implementing an interdisciplinary approach in the k-12 classroom," Eurasia J. Math. Sci. Technol. Educ., vol. 8, no. 4, pp. 223-232, Jan. 2012, doi: 10.12973/eurasia.2012.841a.

[4] K. Osman, L. C. Hiong, and R. Vebrianto, "21st Century Biology: An Interdisciplinary Approach of Biology, Technology, Engineering and Mathematics Education," Procedia - Soc. Behav. Sci., vol. 102, pp. 188-194, Nov. 2013, doi: 10.1016/j.sbspro.2013.10.732.

[5] J. Hayes, "Association for Supervision and Curriculum Development," 1989.

[6] G. Hardy, A. Howes, D. Spendlove, and G. Wake, "Opportunities to confront nad cross subject boundaries: trainee teachers' perceptions of the differences and interrelationships between STEM subjects," 2008. Accessed: Jun. 28, 2020. [Online].

[7] J. A. Ramaley, "Bio2010: Transforming Undergraduate Education for Future Research Biologists (review)," Rev. High. Educ., vol. 27, no. 2, pp. 288-289, 2004, doi: 10.1353/rhe.2003.0071. 
[8] J. B. Labov, A. H. Reid, and K. R. Yamamoto, "Integrated biology and undergraduate science education: A new biology education for the twenty-first century?," CBE Life Sci. Educ., vol. 9, no. 1, pp. 10-16, 2010, doi: 10.1187/cbe.09-12-0092.

[9] K. Jayarajah, R. M. Saat, and R. A. A. Rauf, "A review of science, technology, engineering \& mathematics (STEM) education research from 19992013: A Malaysian perspective," Eurasia J. Math. Sci. Technol. Educ., vol. 10, no. 3, pp. 155-163, Dec. 2014, doi: 10.12973/eurasia.2014.1072a.

[10] N. K. DeJarnette, "Implementing STEAM in the Early Childhood Classroom," Eur. J. STEM Educ., vol. 3, no. 3, 2018, doi: 10.20897/ejsteme/3878.

[11] A. Bagiati, S. Y. Yoon, D. Evangelou, and I. Ngambeki, "Engineering curricula in early education: Describing the landscape of open resources," Early Child. Res. Pract., vol. 12, no. 2, 2010, Accessed: Jun. 28, 2020. [Online].

[12] R. W. Bybee and B. Fuchs, "Editorial Preparing the 21st century workforce: A new reform in science and technology education," Journal of Research in Science Teaching, vol. 43, no. 4. pp. 349-352, Apr. 2006, doi: 10.1002/tea.20147.

[13] R. Narayan, S. Park, D. Peker, and J. Suh, "Students' images of scientists and doing science: An international comparison study," Eurasia J. Math. Sci. Technol. Educ., vol. 9, no. 2, pp. 115-129, Dec. 2013, doi: 10.12973/eurasia.2013.923a. 